Check for updates

Cite this: RSC Adv., 2017, 7, 44804

January 2017

Accepted 13th September 2017

DOI: 10.1039/c7ra00877e

rsc.li/rsc-advances

\section{Ultrasmall titanium oxide/titanium oxynitride composite nanoparticle-embedded carbon nanofiber mats as high-capacity and free-standing electrodes for lithium sulfur batteries $\uparrow$}

\author{
Cho-Long Lee, Chanhoon Kim and Il-Doo Kim (DD *
}

Carbon nanofibers functionalized by ultrasmall titanium based nanoparticles were synthesized as highperformance free-standing sulfur electrodes. With their high affinity to polysulfides and high electrical conductivity, the free-standing lithium-sulfur battery electrodes showed superior cycle retention of $85 \%$ with high reversible capacity of $1107 \mathrm{~mA} \mathrm{~h} \mathrm{~g}^{-1}$ after 100 cycles at $1 \mathrm{C}$.
The demand for next generation rechargeable batteries with high energy densities has been increasing due to the rapid development of wide applications from portable electronics to electric vehicles (EVs) and energy storage systems (ESS). Among many candidates for next generation rechargeable batteries, lithium sulfur ( $\mathrm{Li}-\mathrm{S}$ ) batteries have been intensively studied owing to their extremely high energy density (approximately $2600 \mathrm{~W} \mathrm{~h} \mathrm{~kg}^{-1}$ ) which is significantly higher than that of current lithium-ion batteries (150-200 $\left.\mathrm{W} \mathrm{h} \mathrm{kg}^{-1}\right) .{ }^{1-5}$ However, several drawbacks remain for commercialization of current $\mathrm{Li}-\mathrm{S}$ systems including (i) the poor electrical conductivity $(5 \times$ $10^{-30} \mathrm{~S} \mathrm{~cm}^{-1}$ ) of sulfur at room temperature, (ii) the significant volume change (up to $80 \%$ ) during discharge, (iii) critical safety problems arising from the use of highly reactive Li metal, and (iv) dissolution of highly soluble lithium polysulfide $\left(\mathrm{Li}_{2} \mathrm{~S}_{n}, 4<n<8\right){ }^{6}$

The poor electrical conductivity of sulfur leads to use of a large amount of conductive agents which are not active in electrochemical reactions of $\mathrm{Li}-\mathrm{S}$ batteries. Therefore, the use of conductive agents has to be minimized in a fixed volume of electrodes for high energy density. ${ }^{6,7}$ In addition, the highly soluble polysulfides $\left(\mathrm{Li}_{2} \mathrm{~S}_{x}, 3 \leq x \leq 6\right)$ in the ether-based electrolyte migrate and deposit on the surface of $\mathrm{Li}$ anodes by electrical and chemical reduction, resulting in severe shuttle effect, leading to rapid capacity fading. These parasitic

Department of Materials Science and Engineering, Korea Advanced Institute of Science and Technology (KAIST), 291 Daehak-ro, Yuseong-gu, Daejeon 34141, Republic of Korea.E-mail: idkim@kaist.ac.kr

$\dagger$ Electronic supplementary information (ESI) available: Experimental procedure, photograph and SEM images of as-spun, stabilized, carbonized $\mathrm{TiO}_{2} / \mathrm{TiO}_{x} \mathrm{~N}_{y}-\mathrm{CNF}$ mats, high magnification and low magnification SEM images of $\mathrm{TiO}_{2} / \mathrm{TiO}_{x} \mathrm{~N}_{y}-\mathrm{CNF}$ and CNF mats, XPS survey spectra of the $\mathrm{TiO}_{2} / \mathrm{TiO}_{x} \mathrm{~N}_{y}-\mathrm{CNF}$ mats, the $1^{\text {st }}$ discharge curve of the cells using $\mathrm{TiO}_{2} / \mathrm{TiO}_{x} \mathrm{~N}_{y}-\mathrm{CNF}$ and $\mathrm{CNF}$ current collectors corresponding to impedance spectra, and cycle performance of the pristine cells at $1 \mathrm{C}$ and $0.2 \mathrm{C}$. See DOI: $10.1039 / \mathrm{c} 7 \mathrm{ra00877e}$ reactions trigger other problems including (i) consumption of active sulfur species, (ii) corrosion of Li metal surface, and (iii) polarization of $\mathrm{Li}$ anode arising from formation and deposition of insoluble $\mathrm{Li}_{2} \mathrm{~S}$ and $\mathrm{Li}_{2} \mathrm{~S}_{2}$. Particularly, for the protection of $\mathrm{Li}$ anode, lithium nitrate $\left(\mathrm{LiNO}_{3}\right)$ has been investigated as an effective additive in electrolyte solution to protect $\mathrm{Li}$ anode. ${ }^{\mathbf{8} 9}$ Electrolyte solution with $\mathrm{LiNO}_{3}$ reacts with $\mathrm{Li}$ metal to form protective surface film. However, the addition of $\mathrm{LiNO}_{3}$ cannot be a fundamental solution for dissolution of polysulfides. To prevent and/or minimize polysulfides diffusion, anchoring materials have received great attention due to their polar functional groups which effectively promote the interaction with dissolved polysulfides. ${ }^{\mathbf{1 0 , 1 1}}$ Strong affinities between anchoring materials and polysulfides prevents migration of polysulfides to $\mathrm{Li}$ metal anodes. Among many suggested anchoring materials, transition metal oxides (e.g. $\mathrm{Al}_{2} \mathrm{O}_{3}, \mathrm{La}_{2} \mathrm{O}_{3}$, $\mathrm{SiO}_{2}$, and $\mathrm{TiO}_{2}$ ) have been great candidates due to their strong affinity with polysulfides. ${ }^{6,12-15}$ For example, Cui's group reported the sulfur cathode based on hydrogen reduced $\mathrm{TiO}_{2}$ inverse opal structure which has effectively confined polysulfides in its 3D matrix due to both physical trapping and surface chemical adsorption. ${ }^{6}$ With the unique inverse opal structure, the sulfur cathode delivered a high capacity of approximately $890 \mathrm{~mA} \mathrm{~h} \mathrm{~g}{ }^{-1}$ after 200 cycles at a rate of $0.2 \mathrm{C} .^{6,14,16}$ However, the low active mass loading of $0.8 \mathrm{mg} \mathrm{cm}^{-2}$ as well as complicated synthetic process including atomic layer deposition and subsequent $\mathrm{H}_{2}$ reduction reduces feasibility of the approach taken.

Recently, the combination of liquid polysulfide (catholyte) and a free standing conductive carbon matrix has received much interest owing to its simple and facile route for confinement of liquid polysulfide into conductive matrix. ${ }^{\mathbf{1 1}}$ This approach enables the sulfur active material to simply disperse and distribute in the conductive matrix without the use of conventional melt-diffusion method. However, the interaction 
between liquid polysulfide and the conductive carbon matrix is not sufficient due to the nonpolar nature of carbon. In order to tackle the polysulfide-shuttle issues, strong interaction between liquid polysulfide and the conductive carbon matrix is required for the catholyte system.

Herein, we report carbon nanofibers (CNFs) functionalized by ultrasmall titanium oxide/titanium oxynitride composite nanoparticles $\left(\mathrm{TiO}_{2} / \mathrm{TiO}_{x} \mathrm{~N}_{y} \mathrm{c}-\mathrm{NPs}, 2-5 \mathrm{~nm}\right)$ as high-performance free-standing lithium-sulfur battery electrodes. The ultrasmall functional titanium based nanoparticles embedded in CNFs retain high affinity with polysulfides as well as high electrical conductivity. Furthermore, the use of dissolved polysulfides in electrolyte as active materials for liquid cathode enables us to design electrodes without binder and conductive agent as well as offer a high utilization of active materials owing to high reaction activity of liquid phase. As a consequence, freestanding sulfur electrodes resulted in excellent capacity retention of $85 \%$ with high reversible capacity of $1107 \mathrm{~mA} \mathrm{~h} \mathrm{~g}^{-1}$ after 100 cycles at $1 \mathrm{C}$.

The facile synthetic route of the $\mathrm{TiO}_{2} / \mathrm{TiO}_{x} \mathrm{~N}_{y}$ c-NPs loaded$\mathrm{CNF}$ (hereafter, $\mathrm{TiO}_{2} / \mathrm{TiO}_{x} \mathrm{~N}_{y}-\mathrm{CNF}$ ) mats and the configuration of $\mathrm{Li}$ /dissolved polysulfide electrode using the $\mathrm{TiO}_{2} / \mathrm{TiO}_{x} \mathrm{~N}_{y}-\mathrm{CNF}$ mats (hereafter, $\mathrm{TiO}_{2} / \mathrm{TiO}_{x} \mathrm{~N}_{y}-\mathrm{CNF} @ P S$ ) is schematically illustrated in Fig. 1a. The $\mathrm{TiO}_{2} / \mathrm{TiO}_{x} \mathrm{~N}_{y}-\mathrm{CNF}$ mats were prepared via

(a)
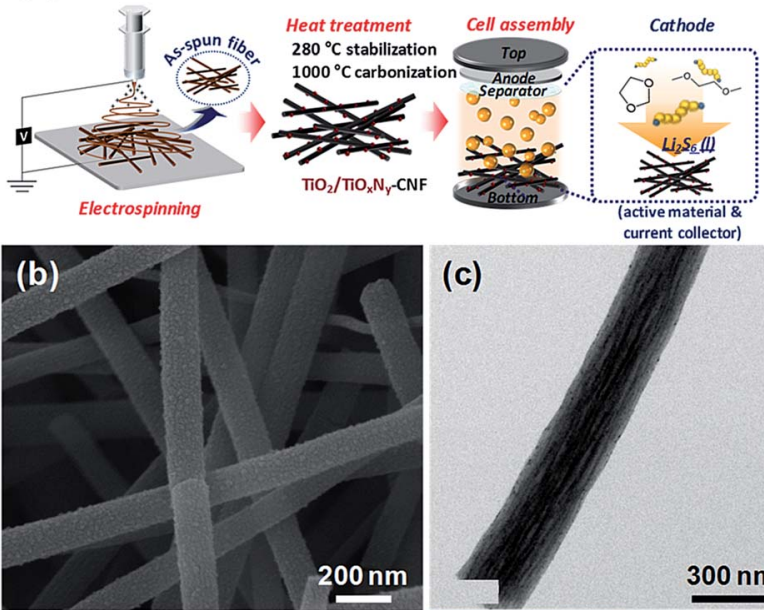

(c)
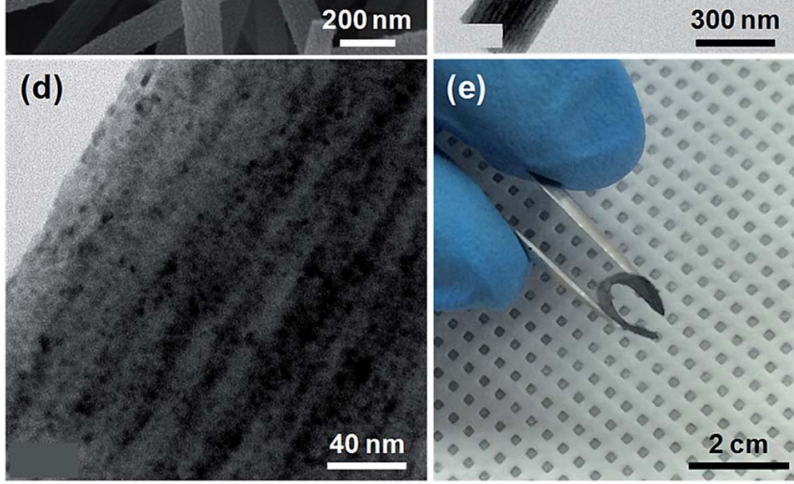

Fig. 1 (a) Schematic illustration of the synthetic route of the $\mathrm{TiO}_{2} /$ $\mathrm{TiO}_{x} \mathrm{~N}_{y}-\mathrm{CNF}$ aPS. (b) SEM, (c) low magnification and (d) high magnification TEM images. (e) Digital photograph showing the high flexibility of as-prepared $\mathrm{TiO}_{2} / \mathrm{TiO}_{x} \mathrm{~N}_{y}-\mathrm{CNF} \mathrm{aPS}$. a simple electrospinning method followed by two-step heat treatment. The CNF backbone offers electronic pathway for active materials and empty space within nanofibers offers accommodation of volume change. The $\mathrm{TiO}_{2} / \mathrm{TiO}_{x} \mathrm{~N}_{y}$ c-NPs in CNFs attract polysulfides near the electrodes and help the facile kinetic reaction of lithium sulfides due to high affinity with sulfur and polysulfide species. For comparison, the pristine CNF mats (control current collector) were prepared via same electrospinning method without the addition of titanium precursor and acetic acid in electrospinning solution.

The microstructural evolution of $\mathrm{TiO}_{2} / \mathrm{TiO}_{x} \mathrm{~N}_{y}-\mathrm{CNF}$ mats was characterized by transmission electron microscopy (TEM) and scanning electron microscopy (SEM). The microstructure and morphologies of the as-synthesized, stabilized, and carbonized nanofibers are shown in Fig. S1. $\dagger$ As shown in photograph images (Fig. S1a, d and $\mathrm{g} \dagger$ ), as-spun nanofibers showed white color, but their color was changed to brown and black during heat treatment. The diameter of nanofibers became thinner and finally $200 \mathrm{~nm}$ after carbonization (Fig. S1†). Many ultrasmall nanoparticles with the size distribution of $2-5 \mathrm{~nm}$ were decorated on the surface of carbonized nanofibers as shown in SEM and TEM images (Fig. 1b-d). The CNF mats including $\mathrm{TiO}_{2} / \mathrm{TiO}_{x} \mathrm{~N}_{y}-\mathrm{CNF}$ showed high flexibility (Fig. 1e). The CNFs without $\mathrm{TiO}_{2} / \mathrm{TiO}_{x} \mathrm{~N}_{y} \mathrm{c}-$ NPs showed similar diameters of about $200 \mathrm{~nm}$ while exhibiting smoother surface compared to $\mathrm{TiO}_{2} / \mathrm{TiO}_{x} \mathrm{~N}_{y}-\mathrm{CNF}$ mats (Fig. S2 $\dagger$ ).

In order to investigate the carbon quality and electrical conductivity of $\mathrm{TiO}_{2} / \mathrm{TiO}_{x} \mathrm{~N}_{y}$ c-NPs-CNFs, we carried out Raman spectroscopy and four-probe measurement. In the Raman spectra, the peak intensity ratio of the D-band to the G-band (known as the $R$-value) indicates the amount of structurally ordered graphite crystallites in the carbonaceous materials (Fig. 2a). ${ }^{17-19}$ The $R$-value of the $\mathrm{TiO}_{2} / \mathrm{TiO}_{x} \mathrm{~N}_{y}-\mathrm{CNF}$ mats was 0.91 which is almost similar to that of reference sample (0.92, CNF mat without $\mathrm{TiO}_{2} / \mathrm{TiO}_{x} \mathrm{~N}_{y}$ c-NPs). According to the $R$ values, both samples exhibited disordered carbon nature. The electrical conductivity of $\mathrm{TiO}_{2} / \mathrm{TiO}_{x} \mathrm{~N}_{y}-\mathrm{CNF}$ and CNF mats were 1.62 and $2.02 \mathrm{~S} \mathrm{~cm}^{-1}$, respectively materials (Fig. 2a). The crystal structure, and the phase composition of $\mathrm{TiO}_{2} / \mathrm{TiO}_{x} \mathrm{~N}_{y}-\mathrm{CNFs}$ were confirmed by X-ray diffraction (XRD) analysis, high-resolution transmission electron microscopy (HRTEM), and X-ray photoelectron spectroscopy (XPS) analysis. The XRD pattern demonstrates the existence of nanoparticles loaded on CNFs, as shown in Fig. 2c. From the XRD pattern, the $\mathrm{TiO}_{2} / \mathrm{TiO}_{x} \mathrm{~N}_{y}-\mathrm{CNF}$ consisted of amorphous carbon derived from CNF mats and crystalline nanoparticles which are positioned between those for TiN (JCPDS card: no. 65-0715) and TiO (JCPDS card: no. 652900), exhibiting the existence of titanium oxynitride, $\mathrm{TiO}_{x} \mathrm{~N}_{y}$. The $\operatorname{TiN}_{x} \mathrm{O}_{y}$ is considered to be solid solution of $\operatorname{TiN}(a=4.241$ $\AA)$ and TiO $(a=4.18 \AA)$ and its lattice parameter is between the reported values of TiO and TiN by Vegard's law. ${ }^{\mathbf{2 0 , 2 1}}$ It was also confirmed by HRTEM analysis (Fig. 2d) that the fringe spacing of $2.10 \pm 0.03 \AA$ corresponds to the $\{200\}$ planes, while the fringe spacing of about $2.43 \pm 0.02 \AA$ corresponds to the $\{111\}$ planes. These values are between the reported values of TiO $(d(200)=2.0900 \AA, d(111)=2.4133 \AA)$ and $\operatorname{TiN}(d(200)=2.1200$ $\AA, d(111)=2.4480 \AA)$. The results of XRD analysis and HRTEM indicated the existence of cubic phase $\mathrm{TiO}_{x} \mathrm{~N}_{y}$. 
(a)

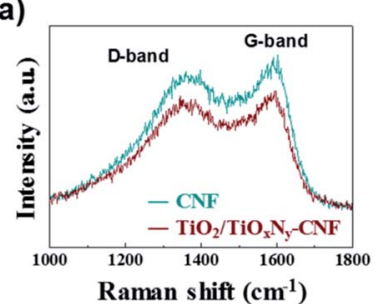

(c)

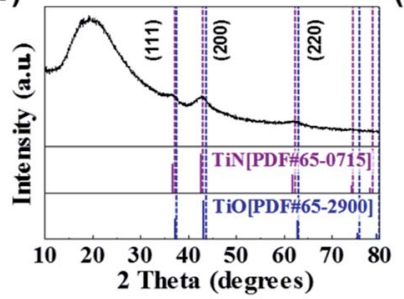

(e)

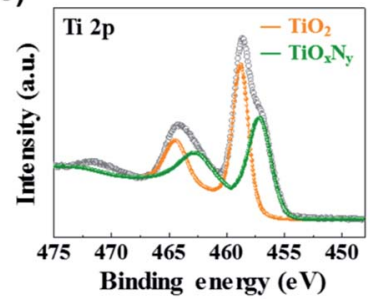

(b)

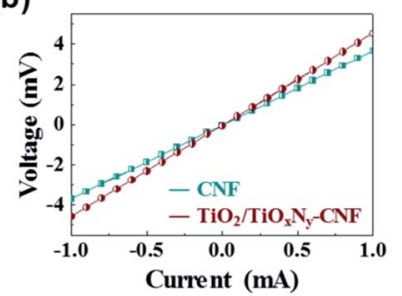

(d)

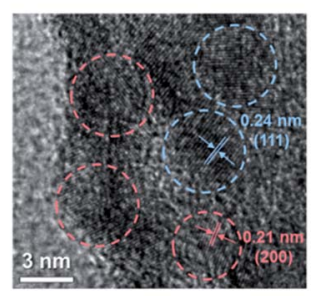

(f)

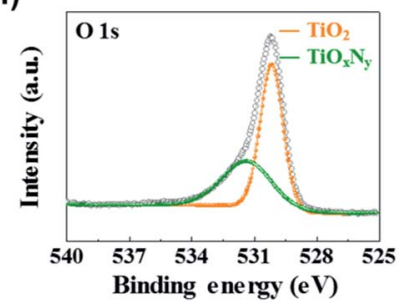

Fig. 2 (a) Raman spectra and (b) I-V curves of $\mathrm{TiO}_{2} / \mathrm{TiO}_{x} \mathrm{~N}_{y}-\mathrm{CNF}$ and CNF mats. (c) XRD pattern, (d) HRTEM analysis, and (e and f) XPS analysis of $\mathrm{TiO}_{2} / \mathrm{TiO}_{x} \mathrm{~N}_{y}-\mathrm{CNF}$ mats.

We further carried out XPS analysis to characterize the chemical compositions of the $\mathrm{TiO}_{2} / \mathrm{TiO}_{x} \mathrm{~N}_{y}$ NPs decorated on the CNFs. The binding energies were calibrated with respect to the $\mathrm{C} 1 \mathrm{~s}$ peak at $284.5 \mathrm{eV}$. According to the XPS spectrum survey, all the peaks can be assigned to elemental $\mathrm{O}, \mathrm{Ti}, \mathrm{N}$ and the $\mathrm{Ti}$ $2 \mathrm{p}_{3 / 2}$ photoemission line can be fitted into two components at $457.08 \mathrm{eV}$ and $458.74 \mathrm{eV}$, which correspond to $\mathrm{TiO}_{x} \mathrm{~N}_{y}$ and $\mathrm{TiO}_{2}$, respectively (Fig. 2e). ${ }^{22-26}$ These values are consistent with the spectra of $\mathrm{O}$ 1s photoelectrons (Fig. 2f), composed of two components centered at 530.18 and $531.36 \mathrm{eV}$, which are characteristic peaks of $\mathrm{TiO}_{2}$ and $\mathrm{TiO}_{x} \mathrm{~N}_{y}$, respectively. ${ }^{22,24,25}$ Interestingly, the $\mathrm{TiO}_{2}$ phase was detected by the XPS analysis which was not shown in the XRD analysis. It could be attributed to the existence of amorphous $\mathrm{TiO}_{2} \cdot{ }^{21,27,28}$ According to the XPS, XRD, and HRTEM analyses, as-synthesized NPs loaded on the CNFs were confirmed as the composite of $\mathrm{TiO}_{2}$ and $\mathrm{TiO}_{x} \mathrm{~N}_{y}$.

Due to the high flexibility of as-synthesized free-standing $\mathrm{TiO}_{2} / \mathrm{TiO}_{x} \mathrm{~N}_{y}-\mathrm{CNF}$ mats, they can be used as 3D current collector without using conventional Al metal foil. The $\mathrm{Li}_{2} \mathrm{~S}_{6}$ solution was prepared for the liquid cathode through a chemical reaction between sulfur (S) and lithium sulfide ( $\left.\mathrm{Li}_{2} \mathrm{~S}\right) .20 \mu \mathrm{l}$ of $\mathrm{Li}_{2} \mathrm{~S}_{6}$ solution was simply dropped on the $3 \mathrm{D}$ current collector and dried for $10 \mathrm{~min}$ in a glove box without any post annealing or vacuum processes. The active mass loading was $2 \mathrm{mg} \mathrm{cm}^{-2}$. Fig. S4 $\uparrow$ shows the first charge/discharge voltage profiles of Li/ dissolved polysulfide electrode using the $\mathrm{TiO}_{2} / \mathrm{TiO}_{x} \mathrm{~N}_{y}-\mathrm{CNF}$ mats $\left(\mathrm{TiO}_{2} / \mathrm{TiO}_{x} \mathrm{~N}_{y}-\mathrm{CNF} @ P S\right)$ and a Li/dissolved polysulfide electrode using the CNF mats (hereafter, CNF@PS) at 0.05C

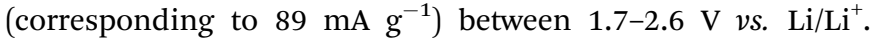
Interestingly, the typical upper voltage plateau of the $\mathrm{Li}-\mathrm{S}$ cells at 2.2-2.3 $\mathrm{V}$ did not appear during the first discharge curve as the reaction started at $\mathrm{Li}_{2} \mathrm{~S}_{6}$ state. The $\mathrm{TiO}_{2} / \mathrm{TiO}_{x} \mathrm{~N}_{y}-\mathrm{CNF} @ P S$ shows lower first discharge capacity $\left(1094 \mathrm{~mA} \mathrm{~h} \mathrm{~g}^{-1}\right)$ than typical first discharge capacity of $\mathrm{S}$ due to the use of $\mathrm{Li}_{2} \mathrm{~S}_{6}$ instead of S. The capacity was calculated solely based on the mass of sulfur. However, the charge capacity of the $\mathrm{TiO}_{2} / \mathrm{TiO}_{x^{-}}$ $\mathrm{N}_{y}$-CNF@PS reached to $1444 \mathrm{~mA} \mathrm{~h} \mathrm{~g}^{-1}$ during the first charge process. The CNF@PS delivered much lower initial discharge/ charge capacities (661.38 and $953.63 \mathrm{~mA} \mathrm{~h} \mathrm{~g}^{-1}$ ) due to the poor affinity to polysulfides. Fig. 3a-d shows cycle performance and charge/discharge voltage profiles of the $\mathrm{TiO}_{2} / \mathrm{TiO}_{x} \mathrm{~N}_{y^{-}}$ CNF@PS and CNF@PS at 0.2C (corresponding to $335 \mathrm{~mA} \mathrm{~g}^{-1}$ ) and $1 \mathrm{C}$ (corresponding to $1675 \mathrm{~mA} \mathrm{~g}^{-1}$ ) between $1.7-2.6 \mathrm{~V} v s$. Li/ $\mathrm{Li}^{+}$. Owing to the high affinity to polysulfides, the $\mathrm{TiO}_{2} / \mathrm{TiO}_{x} \mathrm{~N}_{y^{-}}$ CNF@PS exhibits much higher reversible capacities than CNF@PS during cycling both at 0.2 and 1C, as shown in Fig. 3ad. The $\mathrm{TiO}_{2} / \mathrm{TiO}_{x} \mathrm{~N}_{y}-\mathrm{CNF} @ P S$ retained high reversible capacity of $1107 \mathrm{~mA} \mathrm{~h} \mathrm{~g}^{-1}$ after 100 cycles at 1C, which was as high as $280 \%$ of the capacity of the CNF@PS cells. The increase of specific capacities of both samples during the initial few cycles at $0.2 \mathrm{C}$ could be attributed to the redistribution of polysulfides on the nanofiber network. The polysulfides in the nanofiber network were rearranged and positioned at electrochemically favorable sites during initial charge/discharge process. ${ }^{11,29,30}$

(a)
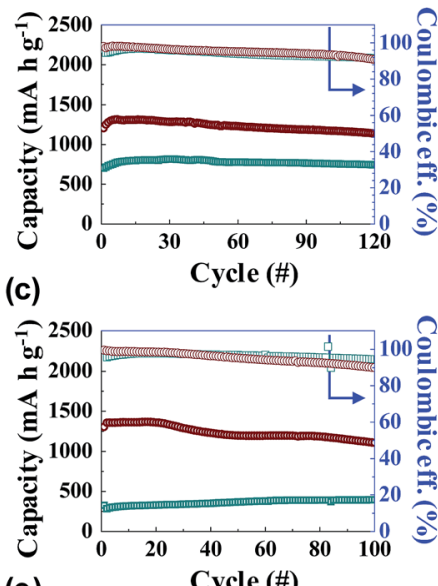

(e)

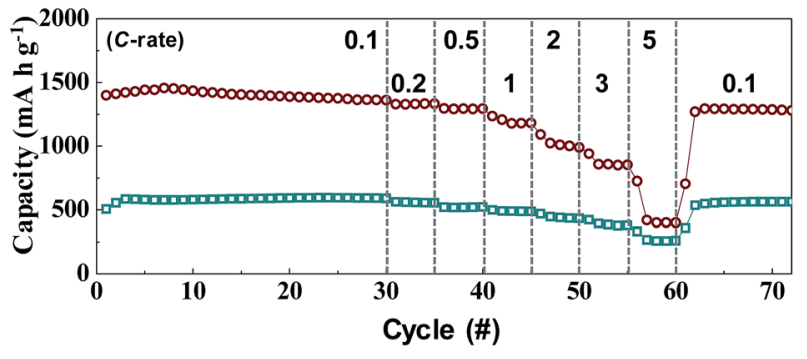

Fig. 3 Cycle performance and charge/discharge voltage profiles of the cells using $\mathrm{TiO}_{2} / \mathrm{TiO}_{x} \mathrm{~N}_{y}-\mathrm{CNF}$ and CNF current collector at (a and b) 0.2 and ( $c$ and d) 1C. (e) Rate capability of the cells using $\mathrm{TiO}_{2}$ / $\mathrm{TiO}_{x} \mathrm{~N}_{y}-\mathrm{CNF}$ and CNF current collector between 1.7-2.6 V vs. $\mathrm{Li} / \mathrm{Li}^{+}$. The current densities of charge and discharge are the same. 
The rate capabilities were also measured in charge/discharge rate (0.1C-5C) between $1.7-2.6 \mathrm{~V} v$ s. $\mathrm{Li} / \mathrm{Li}^{+}$(Fig. 3e). As expected, the $\mathrm{TiO}_{2} / \mathrm{TiO}_{x} \mathrm{~N}_{y}$-CNF@PS delivered much higher reversible capacities throughout all rates. The ultrasmall $\mathrm{TiO}_{2} / \mathrm{TiO}_{x} \mathrm{~N}_{y}$ c-NPs in CNFs significantly increased affinity to polysulfides, which resulted in highly improved reversible capacity of the cells during the cycling. Furthermore, the CNF mats provided sufficient spaces for volume change during the cycling. The synergistic coupling of both rationally designed CNF and ultrasmall $\mathrm{TiO}_{2} / \mathrm{TiO}_{x} \mathrm{~N}_{y}$ c-NPs resulted in the highly improved cycle and rate performances. The effect of the $\mathrm{TiO}_{2} / \mathrm{TiO}_{x} \mathrm{~N}_{y} \mathrm{c}$ NPs decreased as charge/discharge current density increased. As shown in Fig. 3e, $\mathrm{TiO}_{2} / \mathrm{TiO}_{x} \mathrm{~N}_{y}-\mathrm{CNF} @ P S$ and CNF@PS shows slightly different specific capacities at extremely high current density compared to low current densities, because the charge/ discharge current rates were faster than the rate of drawing the polysulfides around the electrode by affinity from $\mathrm{TiO}_{2} / \mathrm{TiO}_{x} \mathrm{~N}_{y}$ c-NPs.

To further confirm the effect of the $\mathrm{TiO}_{2} / \mathrm{TiO}_{x} \mathrm{~N}_{y}$ c-NPs on the cell performance, electrochemical impedance spectroscopy (EIS) was carried out. Fig. 4a and b show the Nyquist plots of the $\mathrm{TiO}_{2} / \mathrm{TiO}_{x} \mathrm{~N}_{y}-\mathrm{CNF} @ P S$ and CNF@PS which were cycled for $1^{\text {st }}$ discharge, and the materials were collected at the end of discharge at $1.7 \mathrm{~V}$. Corresponding three points of each (a)
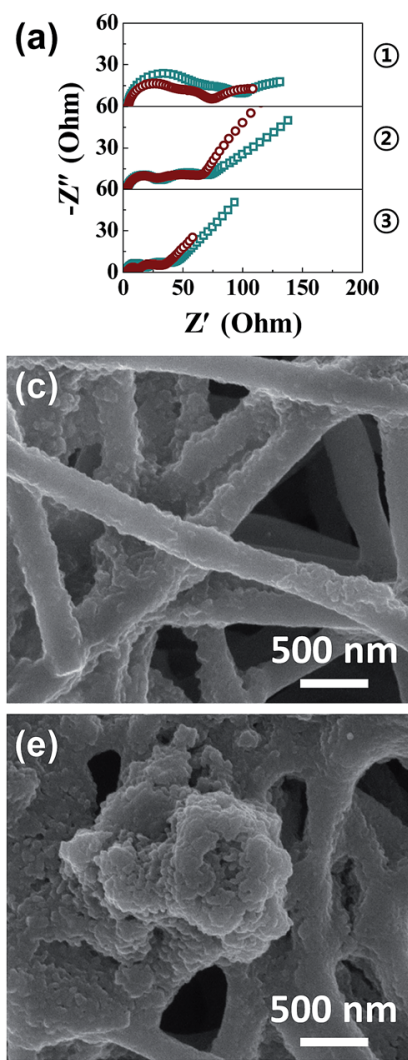

(b)
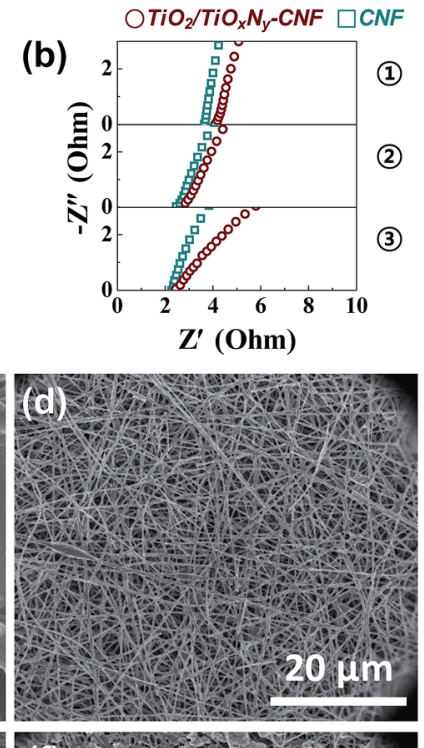

Fig. 4 (a) Overall range and (b) expand range of the Nyquist plots of the cells using $\mathrm{TiO}_{2} / \mathrm{TiO}_{x} \mathrm{~N}_{y}-\mathrm{CNF}$ and CNF current collectors after 1st discharge cycle. Ex situ SEM images of (c and d) the $\mathrm{TiO}_{2} / \mathrm{TiO}_{x} \mathrm{~N}_{y}-\mathrm{CNF}$ and (e and f) CNF mats discharged for $2^{\text {nd }}$ point in Fig. S4.† discharge state for impedance spectra are shown in Fig. S5. $\dagger$ All the spectra show two semicircles at high and medium frequencies and a linear slope at low frequencies, with corresponding equivalent circuit presented in the inset of Fig. S5. $\dagger$ The intercept of highest frequency on the $Z^{\prime}$ axis is the resistance value of the electrolyte solution, i.e., $R_{\mathrm{S}}$. The $R_{\mathrm{S}}$ values of the $\mathrm{TiO}_{2} / \mathrm{TiO}_{x} \mathrm{~N}_{y}-\mathrm{CNF} @ P S$ on three discharge states were higher (4.09, 2.84 and $2.44 \Omega$ for state 1,2 and 3 , respectively) than those of the CNF@PS (3.63, 2.46 and 2.27 $\Omega$ for state 1, 2 and 3, respectively). The $R_{\mathrm{S}}$ values are related to concentration of polysulfides on the electrode surface..$^{31-33}$ Higher concentration of polysulfides on the electrode surface increases the viscosity of electrolyte and leads to increase in the $R_{\mathrm{S}}$ value. Therefore, higher $R_{\mathrm{S}}$ values of $\mathrm{TiO}_{2} / \mathrm{TiO}_{x} \mathrm{~N}_{y}$-CNF@PS are originated from the strong polar-polar affinity of the polysulfides on the $\mathrm{TiO}_{2} /$ $\mathrm{TiO}_{x} \mathrm{~N}_{y}$ c-NPs. As discharge state is deeper, $R_{\mathrm{S}}$ values of both cells were smaller because most of the polysulfides on the interface of solution/electrode were already converted to the lithium sulfides. The intercepts between the medium-frequency semicircles and linear slopes on the $Z^{\prime}$ axis are the charge transfer resistance, i.e., $R_{\mathrm{CT}}$. The $R_{\mathrm{CT}}$ values are related to the reaction kinetics of the soluble polysulfides converted to the insoluble lithium sulfides. ${ }^{11}$ The $\mathrm{TiO}_{2} / \mathrm{TiO}_{x} \mathrm{~N}_{y}$ c-NPs facilitate precipitation and growth processes of lithium sulfide and lead to decreased $R_{\mathrm{CT}}$ values of the $\mathrm{TiO}_{2} / \mathrm{TiO}_{x} \mathrm{~N}_{y}-\mathrm{CNF} @ P S$. According to the EIS analysis results, the improvement of the cell performance including $\mathrm{TiO}_{2} / \mathrm{TiO}_{x} \mathrm{~N}_{y}$ c-NPs can be explained that the NPs attract the polysulfides around the electrode and facilitate reaction kinetics of lithium sulfides. The absorption experiment of polysulfides further supported the EIS results. As shown in Fig. S6, $\uparrow$ the $\mathrm{TiO}_{2} / \mathrm{TiO}_{x} \mathrm{~N}_{y}-\mathrm{CNF}$ shows strong absorption near $415 \mathrm{~nm}$ compared to the CNFs, which indicates that the $\mathrm{TiO}_{2} / \mathrm{TiO}_{x} \mathrm{~N}_{y}-\mathrm{CNF}$ has the stronger entrapment ability toward $\mathrm{Li}_{2} \mathrm{~S}_{6}$ due to the high affinity of ultrasmall $\mathrm{TiO}_{2} / \mathrm{TiO}_{x} \mathrm{~N}_{y}$ nanoparticles to polysulfides. ${ }^{\mathbf{3 4 , 3 5}}$

Furthermore, the $\mathrm{TiO}_{2} / \mathrm{TiO}_{x} \mathrm{~N}_{y}$ c-NPs also contributed to uniform distribution of dissolved lithium sulfides. Fig. $4 \mathrm{c}-\mathrm{f}$ shows the ex situ SEM images of the $\mathrm{TiO}_{2} / \mathrm{TiO}_{x} \mathrm{~N}_{y}-\mathrm{CNF} @ P S$ collected at the end of discharge at $2.0 \mathrm{~V}$ (point 2 in Fig. S5 $\dagger$ ). According to the SEM images, relatively large reduction products with the size distribution of 1.5-4 $\mu \mathrm{m}$ were deposited on the surface of the CNF@PS, whereas very thin layers of lithium sulfides were deposited on the surface of the $\mathrm{TiO}_{2} / \mathrm{TiO}_{x} \mathrm{~N}_{y^{-}}$ CNF@PS. These results indicate that the $\mathrm{TiO}_{2} / \mathrm{TiO}_{x} \mathrm{~N}_{y}-\mathrm{CNFs}$ significantly contribute to uniform deposition of dissolved lithium sulfides and maintain porosity of the CNFs during cycling, which enables to achieve high reversible capacity even at high $\mathrm{C}$ rates.

\section{Conclusions}

In summary, we have synthesized highly flexible and conductive free-standing $\mathrm{TiO}_{2} / \mathrm{TiO}_{x} \mathrm{~N}_{y}-\mathrm{CNF}$ mat by simple electrospinning method for high performance 3D current collector of $\mathrm{Li} /$ dissolved polysulfide cells. The electrospun structure provides empty space among nanofibers for accommodation of volume change and the $\mathrm{TiO}_{2} / \mathrm{TiO}_{x} \mathrm{~N}_{y}$ c-NPs with polar property not only 
significantly improved the redox kinetics of polysulfides, but also provided many active sites for effective deposition of lithium sulfides. Owing to the combination of functional titanium based ultrasmall nanoparticles cells and highly conductive CNFs, the $\mathrm{TiO}_{2} / \mathrm{TiO}_{x} \mathrm{~N}_{y}-\mathrm{CNF} @ P S$ delivered high reversible capacity of $1107 \mathrm{~mA} \mathrm{~h} \mathrm{~g}^{-1}$ after 100 cycles at 1C, respectively. Our functionalized conductive $3 \mathrm{D}$ current concept can be applicable to the development of next-generation sulfur batteries.

\section{Conflicts of interest}

There are no conflicts of interest to declare.

\section{Acknowledgements}

This work was supported by the Korea CCS R\&D Center (KCRC) grant funded by the Korea government (Ministry of Science, ICT \& Future Planning) (no. NRF-2014M1A8A1049303), the Korea Institute of Machinery \& Materials (KIMM) and the National Research Council of Science and Technology (NST), Republic of Korea, and the Wearable Platform Materials Technology Center (WMC) funded by the National Research Foundation of Korea (NRF) Grant of the Korean Government (Ministry of Science, ICT \& Future Planning) (no. 2016R1A5A1009926).

\section{References}

1 M.-K. Song, E. J. Cairns and Y. Zhang, Nanoscale, 2013, 5, 2186-2204.

2 X. Ji and L. F. Nazar, J. Mater. Chem., 2010, 20, 9821-9826.

3 P. G. Bruce, S. A. Freunberger, L. J. Hardwick and J.-M. Tarascon, Nat. Mater., 2012, 11, 19-29.

4 S. S. Zhang, J. Power Sources, 2013, 231, 153-162.

5 R. Van Noorden, Nature, 2014, 507, 26-28.

6 Z. Liang, G. Zheng, W. Li, Z. W. Seh, H. Yao, K. Yan, D. Kong and Y. Cui, ACS Nano, 2014, 8, 5249-5256.

7 C. Kim, S. Choi, S. Yoo, D. Kwon, S. Ko, J. M. Kim, S. Y. Lee, I. D. Kim and S. Park, Nanoscale, 2015, 7, 11286-11290.

8 S. Xiong, K. Xie, Y. Diao and X. Hong, Electrochim. Acta, 2012, 83, 78-86.

9 S. S. Zhang, Electrochim. Acta, 2012, 70, 344-348.

10 Q. Zhang, Y. Wang, Z. W. Seh, Z. Fu, R. Zhang and Y. Cui, Nano Lett., 2015, 15, 3780-3786.

11 H. Yao, G. Zheng, P.-C. Hsu, D. Kong, J. J. Cha, W. Li, Z. W. Seh, M. T. McDowell, K. Yan, Z. Liang, V. K. Narasimhan and Y. Cui, Nat. Commun., 2014, 5, 3943.

12 Y. Choi, B. Jung, D. Lee, J. Jeong, K. Kim, H. Ahn, K. Cho and H. Gu, Phys. Scr., 2007, 2007, 62.
13 F. Sun, J. Wang, D. Long, W. Qiao, L. Ling, C. Lv and R. Cai, J. Mater. Chem. A, 2013, 1, 13283-13289.

14 S. Evers, T. Yim and L. F. Nazar, J. Phys. Chem. C, 2012, 116, 19653-19658.

15 Z. W. Seh, J. H. Yu, W. Li, P.-C. Hsu, H. Wang, Y. Sun, H. Yao, Q. Zhang and Y. Cui, Nat. Commun., 2014, 5, 5017.

16 Q. Pang, D. Kundu, M. Cuisinier and L. Nazar, Nat. Commun., 2014, 5, 4759.

17 P. Joshi, L. Zhang, Q. Chen, D. Galipeau, H. Fong and Q. Qiao, ACS Appl. Mater. Interfaces, 2010, 2, 3572-3577.

18 B. Zhang, Y. Yu, Z. Huang, Y.-B. He, D. Jang, W.-S. Yoon, Y.-W. Mai, F. Kang and J.-K. Kim, Energy Environ. Sci., 2012, 5, 9895-9902.

19 M. Zhi, A. Manivannan, F. Meng and N. Wu, J. Power Sources, 2012, 208, 345-353.

20 X. Yang, C. Li, B. Yang, W. Wang and Y. Qian, Chem. Phys. Lett., 2004, 383, 502-506.

21 M. Zukalova, J. Prochazka, Z. Bastl, J. Duchoslav, L. Rubacek, D. Havlicek and L. Kavan, Chem. Mater., 2010, 22, 40454055.

22 X. Song, D. Gopireddy and C. G. Takoudis, Thin Solid Films, 2008, 516, 6330-6335.

23 H. Man, Z. Cui and X. Yang, Appl. Surf. Sci., 2002, 199, 293302.

24 F.-H. Lu and H.-Y. Chen, Surf. Coat. Technol., 2000, 130, 290296.

25 N. C. Saha and H. G. Tompkins, J. Appl. Phys., 1992, 72, 30723079.

26 Z. Yang, G. Du, Q. Meng, Z. Guo, X. Yu, Z. Chen, T. Guo and R. Zeng, J. Mater. Chem., 2012, 22, 5848-5854.

27 M. Drygas, C. Czosnek, R. T. Paine and J. F. Janik, Chem. Mater., 2006, 18, 3122-3129.

28 A. Trenczek-Zajac, M. Radecka, K. Zakrzewska, A. Brudnik, E. Kusior, S. Bourgeois, M. M. De Lucas and L. Imhoff, $J$. Power Sources, 2009, 194, 93-103.

29 C.-L. Lee and I.-D. Kim, Nanoscale, 2015, 7, 10362-10367.

30 S.-H. Chung and A. Manthiram, Chem. Commun., 2014, 50, 4184-4187.

31 X. Pu, G. Yang and C. Yu, J. Electrochem. Soc., 2015, 162, A1396-A1400.

32 K. Han, J. Shen, S. Hao, H. Ye, C. Wolverton, M. C. Kung and H. H. Kung, ChemSusChem, 2014, 7, 2545-2553.

33 N. A. Cañas, K. Hirose, B. Pascucci, N. Wagner, K. A. Friedrich and R. Hiesgen, Electrochim. Acta, 2013, 97, 42-51.

34 Y. Tao, Y. Wei, Y. Liu, J. Wang, W. Qiao, L. Ling and D. Long, Energy Environ. Sci., 2016, 9, 3230-3239.

35 A. Schneider, J. Janek and T. Brezesinski, Phys. Chem. Chem. Phys., 2017, 19, 8349-8355. 